\title{
Article
}

\section{Absences and Silences: The Representation of the Tea Picker in Colonial and Fair Trade Advertising}

\author{
Ramamurthy, Anandi
}

Available at http://clok.uclan.ac.uk/6581/

Ramamurthy, Anandi (2012) Absences and Silences: The Representation of the Tea Picker in Colonial and Fair Trade Advertising. Visual Culture in Britain, 13 (3). pp. 367-381. ISSN 1471-4787

It is advisable to refer to the publisher's version if you intend to cite from the work. http://dx.doi.org/10.1080/14714787.2012.717457

For more information about UCLan's research in this area go to http://www.uclan.ac.uk/researchgroups/ and search for <name of research Group>.

For information about Research generally at UCLan please go to http://www.uclan.ac.uk/research/

All outputs in CLoK are protected by Intellectual Property Rights law, including Copyright law. Copyright, IPR and Moral Rights for the works on this site are retained by the individual authors and/or other copyright owners. Terms and conditions for use of this material are defined in the policies page.

\section{CLoK}

Central Lancashire online Knowledge www.clok.uclan.ac.uk

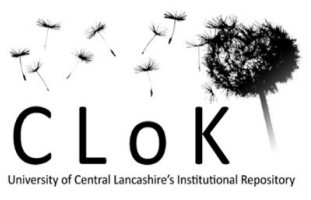




\section{Absences and Silences: The Representation of the Tea Picker in Colonial and Fair Trade Advertising}

The new millennium has seen an increase in the presence of fair trade products, not simply in the ethically conscious niche or charity stores but in the largest supermarkets in the country.1 Ethical consumption as a form of consumerism has been discussed as an expression of the marrying of pleasure and shame. 2 It suggests that there can be a benign formof globalization where consumers can effect positive change by exercising the 'choice' of buying fair trade. 3 In marketing this choice, fair trade advertising of tea, cocoa and coffee, in particular, has adopted the image of the smiling and happy worker from the South, often in theirworking environment, testifying by their presence and their smile to the ethical and moral nature of the product. The image of the smiling and contented worker has a long history in colonial advertising. 4 It was used to assert the 'naturalness' of a racial hierarchy where colonial workers were organized by British firms to enable them to be productive. In the 1950s, during the era of decolonization, very few images of black people were used on consumer products. In the 1970s, however, the image of the labourer from the South re-emergedmost prominently in the form of the South Asian woman on PG Tips advertising. Hers is one of the most enduring images of South Asian women in British advertising and although no longer used on British domestic packaging, it, continues to be used on catering packs in the UK and domestic packaging in New Zealand. Why has this image of the demure and contented South Asian woman tea picker had such longevity? PG Tips used it from the 1970s onwards when anti-racism in British and Western popular cultural discourses grew profoundly, following the civil rights movement in America, a rising anti-racist movement in Britain and the struggle against apartheid in South Africa. Why did it disappear from UK domestic packaging? And does its re-emergence on fair trade products suggest continuities or discontinuities in its meaning?

The recent interest in 'affect' has been my starting point for considering the impact of the PG Tips and later fair trade images on tea advertising in particular. I read these advertisements as texts that articulate discourses in support of company interests, wider racist attitudes, as well as ones that construct an 'affective response' among consumers. Advertisers have always been concernedwith appealing to consumers in ways that are both logical and illogical; they are not afraid to appeal to the non-conscious and subconscious mind. They revel in understanding the effects of visualmessages and stimuli that are not grounded in reason. I explore here the affect induced by the representation of the feminized worker, her smile and the space she is visualized as inhabiting, to considerwhy the PGTips image in particular and other similar images have been so widespread and continue to have an impact on fair trade advertising today. Advertising images are not simply tolerated by us, they 'speak' to us in complex ways urging us to identify with the subjects of the image. In analysing this particular image I will consider the way in which it intersects with gendered articulations and domestic spaces along with cultural and political attitudes to produce its 'affect'. 
Historically, advertising has hidden the context of production, fetishizing commodities to create imaginary worlds of fantasy in which consumption provides us with happiness and emotional satisfaction.5 This has meant that the representation of manual, industrial labour has been rare. When such labour is represented in advertising it is often romanticized as 'individual' and purposeful as, for example, in the Jack Daniel's advertisements with the mythical character, Billy Durm, hand-making individual casks of whiskey for our consumption, or the image of the family bakery to represent the production of a loaf of Hovis.6 In this process, the representation of industrial labour has been domesticated. Usually carried out by women, domestic work has been undervalued in capitalism. It is invested with 'immaterial' and affective labour.7 Such labour, as Hardt and Negri identify,'produces an immaterial good, such as a service, a cultural product, knowledge, or communication'.8 'It transforms the person who uses it ... [and] produces first and foremost a "social relationship", .9 In these advertisements, the exploitation of industrial labour is not only re-worked but the relationship between producer and consumer is also changed through the form of social communication offered in the advertisement, where 'affective labour' is visualized as opposed to traditional manual labour. Affective labour has been more regularly represented in advertisements for service-sector industries such as tourism and catering.

Historically, in products involving colonial labour, images of manual work are more apparent, since racism naturalized black people as born to labour. Tropical produce such as tea, coffee and cocoa has therefore lent itself to the representation of the labourer at work.

Nineteenth-century tea advertising frequently showed the context of production. I have argued previously that this was possible and desirable for tea companies, wanting to assert particular systems of colonial organization in the debates over ways of administering control that emerged as the Empire grew in size. For the plantation owner (including the tea manufacturers), direct rule and direct control over production was the desired framework. This was different from the cocoa/chocolate manufacturers, for example, who were content - and found it in the end preferable - to buy their raw materials from smallholders in the market place.10 The image of plantation production as idyllicwas produced by Lipton's fromthe 1890s onwards and provides an example of the representation of industrial labour within advertising, made possible 'because of the contemporary belief in racial hierarchy'11whereby Africans and Asians were believed to have been born to labour. Lipton's advertisements were also significant because they became one of the dominant representations of South Asians in commercial culture at the time. Lipton'swas thereforewas not simply reiterating a racist precept, but actively contributing to the popularization of a particular racialized discourse among the British public.

As attitudes to colonialism changed, the image of the plantation receded to a backdrop, giving precedence to the more exoticized image of the Sri Lankan woman tea worker. Exoticism has always been present in creating an image for tea and Lipton's first image represented an 'exotic belle' holding a cup, smiling demurely out at the viewer. The embracing of this image in the 1920s and beyond, however, can be seen as the representation 
of imperial control through a 'softer' gendered hierarchy that naturalized the East as female and the West as male. In previous studies of tea advertising I have focused on what was present in the images rather than the absences or silences that were also creating meaning. I focused more on asserting the companies' apparent consciousness in developing representations and less on why this image was so enduring. The concept of affect offers a way to explore this issue, since affect, as Brian Massumi argues, is a non-conscious experience of intensity, a moment of unformed and unstructured potential of feeling and emotion which cannot be fully realized in language.12 Eric Shouse distinguishes affect from feelings and emotions, suggesting that affects are 'pre-personal' as opposed to feelings, which are 'personal and biographical', and emotions that are 'social' - in other words, affect is our unconscious response which precedes our conscious feelings and decisions.13 'Affect', as Spinoza and Deleuze articulate, 'presupposes an idea' but is 'not reducible to the ideas one has'. Yet, while affects are intensities and sensations, these intensities unfold in a context. 'They are temporal and spatial constellations ... impressed in legacies of the past and itineraries of the present/future'.14 Different affects, namely joy and sadness as Spinoza notes, increase or decrease our 'power of acting' and in this sense are part of a socialised experience. 15 To begin, I return to two fairly early Lipton's advertisements from 1896. In my book, Imperial Persuaders, I note that the first of these two images was used only once whereas the second was repeated through 1896 and later. I comment on how order was associated with European dominance and direct control over production (Figures 1 and 2) and note how in the first image the sense of order is less pronounced and how the workers appear to have a relationship between themselves that undermines the Lipton's image of total colonial control over production (direct from tea garden to teapot) by appearing to exclude the planter from their exchange. While this is clearly the case there are other important points to consider. The workers in the second image are diminished to figures without 'presence' upon whom the colonial consumer gazes as silent subjects. The second image is also aesthetically satisfying for a number of reasons, so increasing the intensity of 'affect'. The central circle is lighter and more airy. It creates a feeling of comfort and tranquillity. We are also encouraged to enter the space visually, a broad path at the front of the scene allows our eye to travel to the Lipton's factory and beyond into the serenity of the hills. The image appeals to an aesthetic sensibility, which enables us to view Lipton's as part of a natural order. This iconic image, which thus elicits an aesthetic response, is the one repeated later in the year while the slogans/designs surrounding it change. The factory, renamed 'tea garden', already begins to evoke an idealized space although hierarchy is still present and affirmed within the colonial context.

As early as 1901 Lipton's affirmed the space of the tea estate as a domesticated garden through advertisements and posters that focused on 'exotic' women represented as leisured, despite the presence of the 


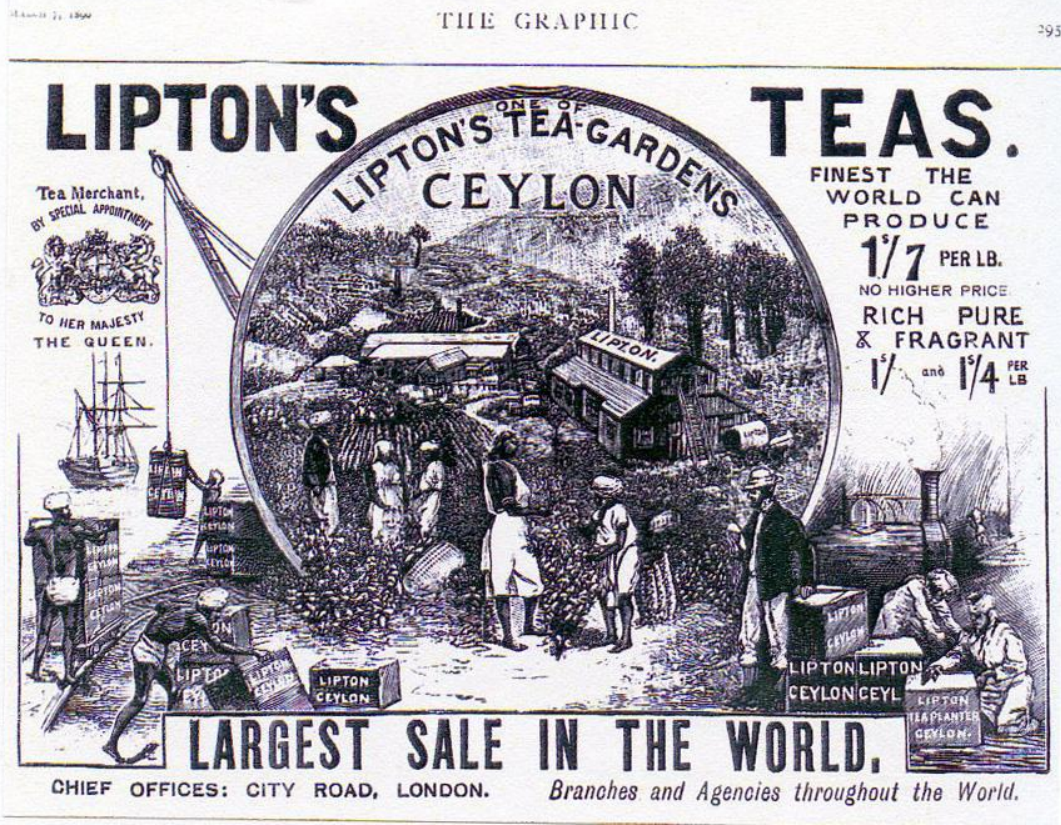

Advertisement, The Graphic,

7 March 1896.

Figure 1. Lipton's Tea

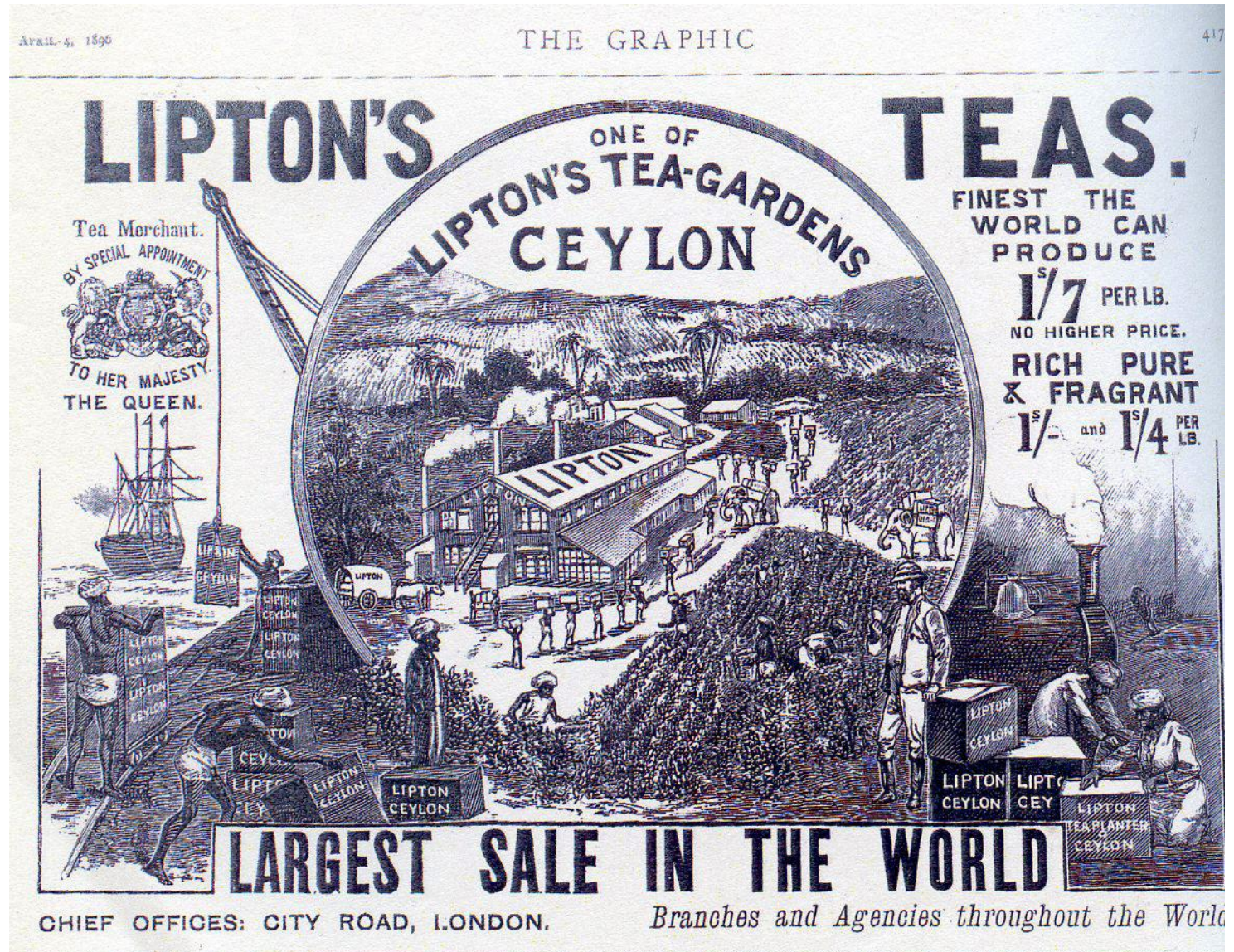

Figure 2. Lipton's Tea

Advertisement, The Graphic,

4 April 1896.

plantation in the background. In one poster, such a woman is even labelled 'the belle' of the Dambatene tea estate, standing beside a crate of tea with 
parasol in hand and flowers in her hair (Figure 3). She is an ambiguous

figure, neither planter's wife (where she would act as a symbol of leisure

and consumption) nor worker, but an exotic, sexualized figure for consumption

by the European viewer. Her ambiguous status is increased by

the spatial ambiguity of the setting - domesticated garden with potted

plant in the foreground and plantation with workers in the background.

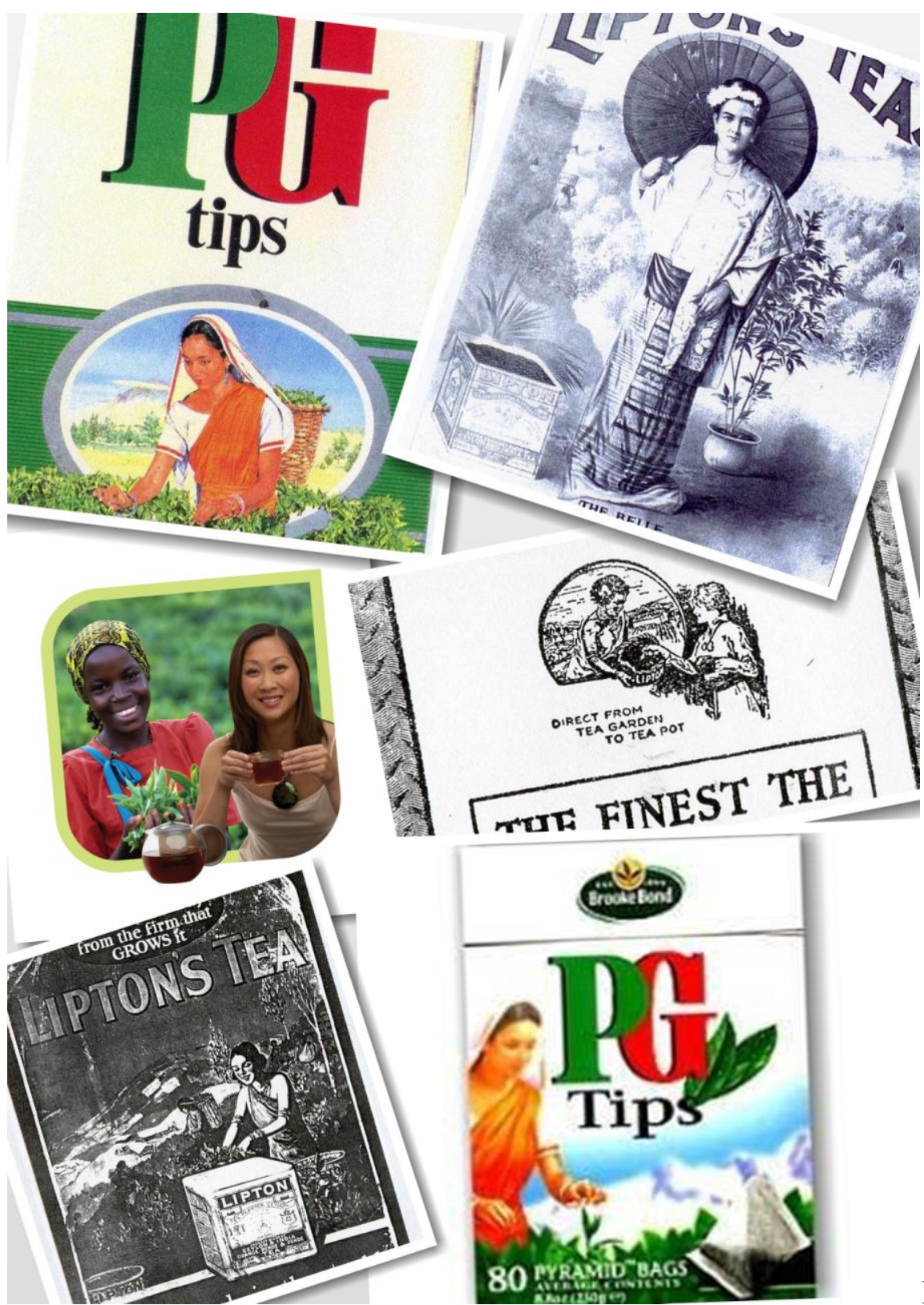

Figure 3. 'Partnerships?'

The metaphor of the garden and women's association with it has a long history as both an idealized space and a space of transgression.16 The space matches Foucault's definition of heterotopias: 'formed in the very founding of society - which are something like counter-sites, a kind of effectively enacted utopia in which the real sites, all the other real sites that can be found within the culture, are simultaneously represented, contested, and inverted'.17 The visualization of such a heterotopian space effortlessly absorbs the contests and inversions of culture - namely colonial hierarchies. 
The visual representation of the 'belle' acts as both an exotic object for our consumption and a representation of a figure that blurs the boundaries between consumer and labourer.

The notion of the domestic space as heterotopian has been interrogated in Gutierrez Rodriguez's consideration of affect in the spaces that domestic workers occupy in private households in Germany. While the domestic space as home is generally perceived as private and is idealized as protective and a place of relaxation, it is the opposite for the domestic worker who labours there, creating a heterogeneous space that is influenced by affective bonds. Rodriguez has argued that a deconstructive reading of affect can add to our understanding of 'the speaking subject' embedded within the discursive framework, as well as the 'intensity' of encounters among domestic workers and their employers, where the domestic worker is both present and absent - bodily present yet 'ghost' at the same time.18 While Rodriguez is writing about a very different issue in the context of ethnographic research, the heterogeneous nature of the space parallels that of the image of the 'tea garden', constructed as both idealized space and place of labour. The visualization of the worker as feminized also enables the reconstruction of the tea garden as domestic because of the way in which women are associated with domesticity in culture. It appears to be a natural order. Second, the presence/absence of the domestic worker is another point worth considering in relation to the representation of workers in tea advertising.

How does understanding the consumer's subject position in relation to the visualized worker enable us to explore how an emotional response is maintained in the tea ads in historically changing circumstances? An analysis of affect in advertising may aid in exploring how discourses of development have interlinked with colonial, racialized and gendered discourses to create the enduring image of the tea picker on so much fair trade tea advertising today. Affect does not work independently and feelings and emotions that are social impinge on its possible impact. By the early twentieth century the conflicting discourses on the legitimacy of colonialism meant that the feelings of order, calm and stability that could be absorbed through our aesthetic interaction with the early Illustrated London News images were undermined by the powerful dominance of rational debates about colonialism. The silent subjects of the 1896 image were no longer silent in the struggle against colonialism. Nonetheless, the reorganization of the space of the plantation into a visual manifestation of a heterotopian space of 'garden'/exotic landscape, which encouraged the viewer to conflate the worker/planter with the consumer through images of the exotic 'belle', enabled the image of the labourer to endure through idealization. Her image also hints at the sexual fantasies that operated within colonial societies of the exotic and sexualized 'other'.19 As the language of colonialism in the 1920s changed to affirm the importance of partnership, images of the producer interacting with or acting as the consumer in the domestic space of the garden emerged repeatedly. The slogan 'From the tea garden to the tea pot' in one popular image from the mid-1920s is visualized in terms of an intimate exchange between two women who smile and share the produce of tea in an exchange reminiscent of women's support for each other as neighbours 
or mothers, both sharing the experience of domesticity (Figure 3). The tea picker leans out of her window from the plantation (her home). The domestic as a space of nurture and privacy, along with the smile on the female labourer's face and the adornment of a flower in her hair, hides the experience of labour and exploitation. That image mapped the ideology of the Empire Marketing Board that promoted empire as a partnership of mutual benefit for Britain and the colonies. 20

In another image from 1922, the tea picker appears to be European and her position in space associates her with the producer, but her features and mannerisms invite us to see her as representative of the consumer (Figure 3). She seems to step into the garden to pick the freshest leaves for her family. The conflation of worker and consumer/leisured individual through the language of the domestic encouraged by the gendered representations of mother and female worker is similar to that space occupied by the workers that Rodriguez interviews who occupy domestic and intimate spaces but at the same time are left as ghosts, non-inhabitants of those spaces. One of Rodriguez's interviewees alludes to herself as ghost: 'To feel within it totally invisible and also completely worthless because there ... is no thank you, no, ah, there you are again, you feel like a ghost.'21 Similarly, the domestication of the image of the tea picker turns the experience of labour into a ghost-like experience. The consumer/ worker (she is most definitely consumer first) smiles, oblivious of the other 'real' workers in the distance who carry their baskets on their heads. Her smile acts to affirmher - consumer and tea picker's - happiness and contentment with her lot. Her smile, like that of all smiling workers, silences these subjects who are 'unable to speak the truth about themselves'. 22 By evoking an image of domesticity and traditional femininity these images are able to suggest for the consumer feelings of intimacy and tranquillity in varying degrees of intensity and in the process hide the social relations of production at the very moment that they are visualized. The ghosting of her labour and the privileging of her image as consumer also fits with the development of advertising in the late twentieth century. Since the 1960s, advertising and consumer culture as a whole have emphasized a world of consumption over production. We are encouraged to see ourselves as consumers, creating our identities from consumer choices rather than as a result of our working lives. Pleasure and leisure are the foremost visualized experiences.23 The absence of representations of our own working lives makes it doubly easy for us to accept the romanticized and mystified representation of distant working environments as 'reality'. We privilege our understanding of individuals as consumers rather than producers and are able to perceive forms of labour as life-style choices rather than social realities. It is for this reason - the fact that in the moment of her exposure her exploitation is denied - that the image of the tea picker endured so effectively into the late twentieth century and beyond. The most striking example of the image of the tea picker in the 1980s and 1990s was on PG Tips advertising. Her image was an icon of the brand and was used by the company to express quality and authenticity (Figure 3). Just like the Lipton's image of 1925 showing the tea picker smiling and sharing her produce with the consumer through the window/picture frame from which she emerges, the PG Tips icon leans out of her oval 
frame and the 'domestication' of the scene is encouraged by the tea plants that cascade out of that same frame through which she appears. There is no sign of the plantation, the leaves adorn the space just as decorative plants adorn our homes and it is these leaves that she symbolically picks for our consumption. She exudes a traditional femininity, demure, almost pious with her head bowed and a slight smile. Her orange sari and red-trimmed shawl and blouse provide a cheerful contrast to the green leaves and band on the packaging. Her light shawl masks the weight of the basket hanging from her head. The use of orange is also significant.While the PG Tips logo is green and red, it is only the trim on her blouse and shawl that are red. Orange 'is considered a colour that stimulates enthusiasm and creativity, while red is associated with fiery heat, orange is associated with the benign warmth of the sun'.24 Orange is a friendly colour in popular discourse, one that can attract attention and induce physical responses in us that include stimulating appetite and activity and encouraging socialization.25 The difference between this and the previous images referred to is that here the conflation is not made between consumer and worker, but between domestic labour and plantation labour, enabled through the gendered and racialized image of the tea picker, which is evoked through the symbolic association of the garden. It is the space that she occupies, as much as anything else that has given her longevity - and creates an intensified feeling of a natural order. This natural order also asserts the people of the South as producers and those of the North as consumers in a similar way to the colonial advertising of the 1920s.

Just as an affective bond felt from an image of ordered workers prior to the 1920s proved impossible to maintain beyond the 1920s, so too as the millennium approached and debates over fair trade began to emerge, the presence of the Indian woman tea picker began to prove problematic.

Shaheen Merali, for example, reworked the PG Tips image with the slogan '80 exploitation flow bags' in a batik from the late 1980s and concerns over unfair trading relations led to the establishment of the Max Havelaar Foundation in 1992 to pioneer fair trade from a niche to a mainstream consumer market.26 Unilever's response was the gradual fading and then removal of the South Asian woman worker as the brand image for PG Tips (Figure 3). Her erasure seems to map her 'ghosted' labour through the conflation of consumer and producer as well as that of domestic and industrial spaces. The romance of her image, once converted from graphic to photographic image (an image type which we associate with 'truth' and reality), 27 could be maintained only through fading her image or through the context of nostalgia. In her representation from 2003, she is almost literally not there, in exactly the same way as the migrant domestic worker maintains a ghost-like existence in the middle-class households in which she works. The older more assertive tea picker image from the 1970s and 1980s is maintained only in commercial nostalgia on tea tins or on aprons with which the invariably female consumer can inhabit the graphic design, another form of consumption of the body of the worker. Finally, of course, she is replaced by the playful monkey who inhabits the symbolic plantation on the new packaging, intensifying the feeling of plantation as leisured space. 28

As the tranquil image of the tea worker disappeared from mainstream 
tea packaging and advertising in the 2000s as a result of the rise of 'fair trade', it began to take root as a sign of quality on products with the fair trade logo where the workers' conditions of employment have become a feature/factor in purchase decisions and therefore have to be explicitly advertised.29 The appearance of workers on fair trade advertising has been described as an act of de-fetishization, since fair trade aims to change market relations to advertise the conditions of production explicitly30 in order to "make transparent the relations under which commodities are exchanged. This is intended to form part of the use value of the commodity 31 and as such transforms the unveiled concrete labour itself into a commodity'.32 In much fair trade advertising and packaging the often smiling worker assents to our consumption. Affect is crucial in our reception of these images. First, workers' smiles enable an affective bond between producer and consumer - we view them as the privileged few in a global neo-liberal economy where we know trade to be dominated by exploitative and often uncertain conditions. Their smiles affirm their contentment with their conditions. Our pleasure, even hedonism in consumption can be excused by a feeling that we are morally 'good' in our fair trade choice33 (Figure 4). The fair trade foundations' campaigning images, for example, depict producers and consumers smiling together.34 We see the producers through a window that graphically reproduces the Liptons 1920s image of colonial partnership. The producers hold the raw materials while the Northern consumers on our side of the window hold the tea or other tropical produce for consumption. Both smile as broadly at each other, suggesting through juxtaposition their mutual contentment.

Recently, Kalpana Wilson has noted how Western feminist discourses of Third World women's agency construct images of women from the Global South as contented because of their efficiency and resourcefulness, ignoring the gender inequalities that force women to act in this way and for which they seek a transformative agenda.35 In a recent article, Wilson has highlighted the visualization of Third World workers in charity advertising as affirming neo-liberal attitudes to development through racialized and gendered hierarchies where women are represented as positive and asserting agency despite the limitations of their lot. Wilson has commented on the way in which images in Oxfam Unwrapped and fair trade chocolate advertising represent the smiling subjects, usually women, as empowered by their own labour - 'a " "participating . . hardworking, industrious and Downloaded by [Anandi Ramamurthy] at 10:09 17 November 2012 self-determined"' subject'.36 Smiling, which has been discussed in literature on race, gender and oppression, is often an important action in affect, as Marilyn Frye has highlighted: "it is often a requirement upon oppressed people that we smile and be cheerful. If we comply, we signal our docility and our acquiescence in our situation.We need not, then, be taken note of. We acquiesce in being made invisible, in our occupying no space. We participate in our own erasure.' 37 Fair trade advertising and publicity promoting fair trade on the basis of fairness requires workers to perform 


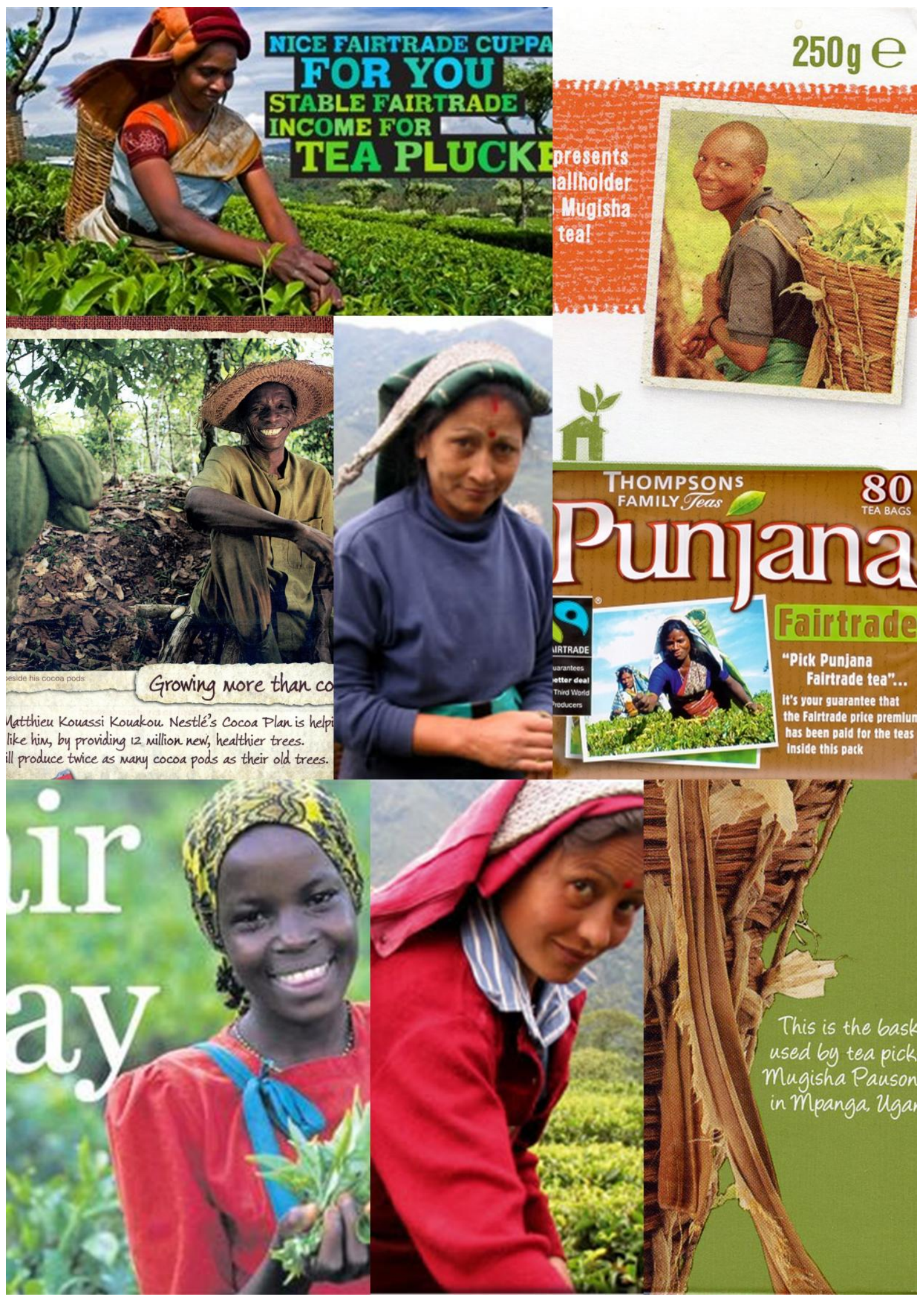

Figure 4. 'Silences and

Smiles'. Special thanks to

Equal Exchange. 
their contentment for our consumption, just as the colonial worker did. This performance of emotional labour, as Rothschild notes, 'requires one to induce or suppress feeling in order to sustain the outward countenance that produces the proper state of mind in others [i.e. the affect] ... This kind of labour calls for a coordination of mind and feeling, and it sometimes draws on a source of self that we honor as deep and integral to our individuality.' 38 It is to these issues that Foucault refers when he asks: 'at what price can subjects speak the truth about themselves?'39

While Wilson focuses on the gendered aspect of the smiling worker and, as I have shown, gender has been a key factor in the way identification is created between producer and consumer in the tea advertisements, recently the images of the smiling worker have broadened to include a significant number of men. As Marilyn Frye and Patricia Chong highlight, the performance of smiling and emotional labour is a manifestation of oppression generally. Both Caf'e Direct and Nestl'e, in their tea and cocoa advertising, have used images of male plantation workers who smile broadly to signify their apparent contentment. Both companies name the workers that they represent. Matthieu sits beside his cocoa pods and significantly it is he rather than the cocoa pods that is in focus (Figure 4). For Caf'e Direct, worker Mugisha Pauson smiles out at us from the back of the packet (Figure 4). A company dedicated to fair trade and another known for their aggressive marketing of breast milk substitutes, a practice which the authors Annette Beasley and Lisa Amir argue has led to the deaths of over 3000 infants every day, adopt the same image for similar effect.40 Both companies market their produce by declaring their dedication to benign, compassionate development. Caf'e Direct asserts 'we are the growers', an ambiguous slogan that could refer to the production of tea as well as the growth of the firm. The firm emphasizes its support for smallholders by informing us that 50 per cent of its profits to date are re-invested to 'strengthen grower livelihoods' (and presumably the firm's). The image of growth is also asserted by Nestl'e, which declares that it is 'growing more than cocoa'. The advertisement tells us of the 12 million healthier cocoa trees that Nestl'e is providing for farmers in West Africa as part of the development of the industry. These claims create an affective bond between us and the company through the image of the workers, which humanizes the statements.

By identifying with the human being at the other end of the supply chain we are encouraged to pay the premium for fair trade tea. Caf'e Direct even encourages us to 'visit' Mugisha online at cafedirect.co.uk, although, when we do, we see only an image of Mpanga in Uganda where Mugisha works. Mpanga is represented as a luscious field of tea plants bathed in sunlight.41 Most significantly, this attempt to individualize the workers, to bring them into our home, highlights and draws attention to the relationship between the domestic workers that Gutierrez discusses and these fair trade workers brought to us by the tea, cocoa and coffee companies. Just like the domestic worker who is present, smiles and pretends to be happy and performs the emotional labour of domestic support, these images erase the actual conditions of the workers' lives, performing as happy and contented workers for our emotional satisfaction. It makes a better cup of tea. The 'ghosting' of their experience is most emphatically brought home by the fact that 
'Mugisha' (if an actual worker) is there to serve the fair trade image when and where it is suitable. Absent from the page on Mpanga in Uganda, he emerges on the Caf'e Direct website as Kenyan in February 2012.42 He now smiles for us as Kenyan. His own story and history is erased.

Caf'e Direct's marketing also features Mugisha Pauson's tea basket on the front of the packaging (Figure 4). This is, it is implied, 'hand-crafted tea', affirmed by the 'hand-crafted basket' in which it is collected - the opposite of industrial labour, drawing on the fetishized image of the labour environment so common in mainstream advertising. This is the kind of natural wicker basket that we buy from home improvement stores to organize our things. The photographic detail of the image encourages us to dwell on the texture and beauty of the basket filled with fresh leaves, not on the labour involved in filling it, the weight of such a basket or the strain of carrying it. In fact, its representation as filled and overflowing echoes the images of over-abundance that we often see in food advertising, depicted so as to exude the pleasure of consumption. Here that pleasure is experienced guilt free, sanctioned by Mugisha's smile as he assents to our consumption, providing through his silence a fetishized image of his working environment where the smallholder's position is romanticized as benign in comparison with industrial labour.

The implied 'empowerment' of workers in fair trade plantations ignores the structural inequalities that persist in relation to both gender and northsouth relations. As Varul notes, there is no criterion for fairness in the current fair trade discourse that protects workers from the South. We therefore take for granted the levels of fairness for workers in advanced capitalist countries as the meaning of the fair trade logo.43 When we consider the continued inequalities, the smile of these seemingly 'empowered' workers denies the unequal conditions that continue to permeate global trading relations, which are the opposite of fair. The fair trade logo listed on vast amounts of packaging states that the tea is sourced 'from Fairtrade certified plantations and small-scale farmers' and that '[p]roducers supplying Fairtrade products receive a price that covers the cost of production. In addition, they receive a Fairtrade Premium which allows the local community to invest in social, environmental and economic development projects of their own.' 44 Yet these guarantees are frequently flouted as, for example, the 2007 documentary The Bitter Taste of Tea highlighted. Fair trade premiums have been used to replace roofs in workers' residences, which should have been provided by the employers, and the workers the documentary makers interviewed pointed out that there was no health care provision and that they were paid only for what they picked. Some even looked back to the 'good old days' of colonialism when children were at least sent to school and health care was provided by the estate, a nostalgic memory but nevertheless important in how they view their lot today. 45

The difficulty of maintaining fair trade guarantees has led the Max Havelaar Foundation to dilute even further the basic guarantees that the foundation formerly put in place. More recently the fair trade brand simply 'aims' to create sustainable production: 'For producers Fairtrade means prices that aim to cover the costs of sustainable production, an 
additional Fairtrade Premium, advance credit, longer term trade relationships, and decent working conditions for hired labour.' 46 In promoting itself through the marketing of its product, fair trade has created a 'brand' which needs nurturing and protecting like any other. The worker's smile is central to the affect - the intensity of feeling that is created in us to encourage us to pay the premium for the label. Photographers, including those who have been committed to 'fair trade' and charity advertising, are sensitive to this 'need' or requirement from their clients. While their portfolios contain an array of images that respect the intense labour of their subjects, many of those chosen for reproduction by journals and advertisers maintain the image of smiling contentment. 47

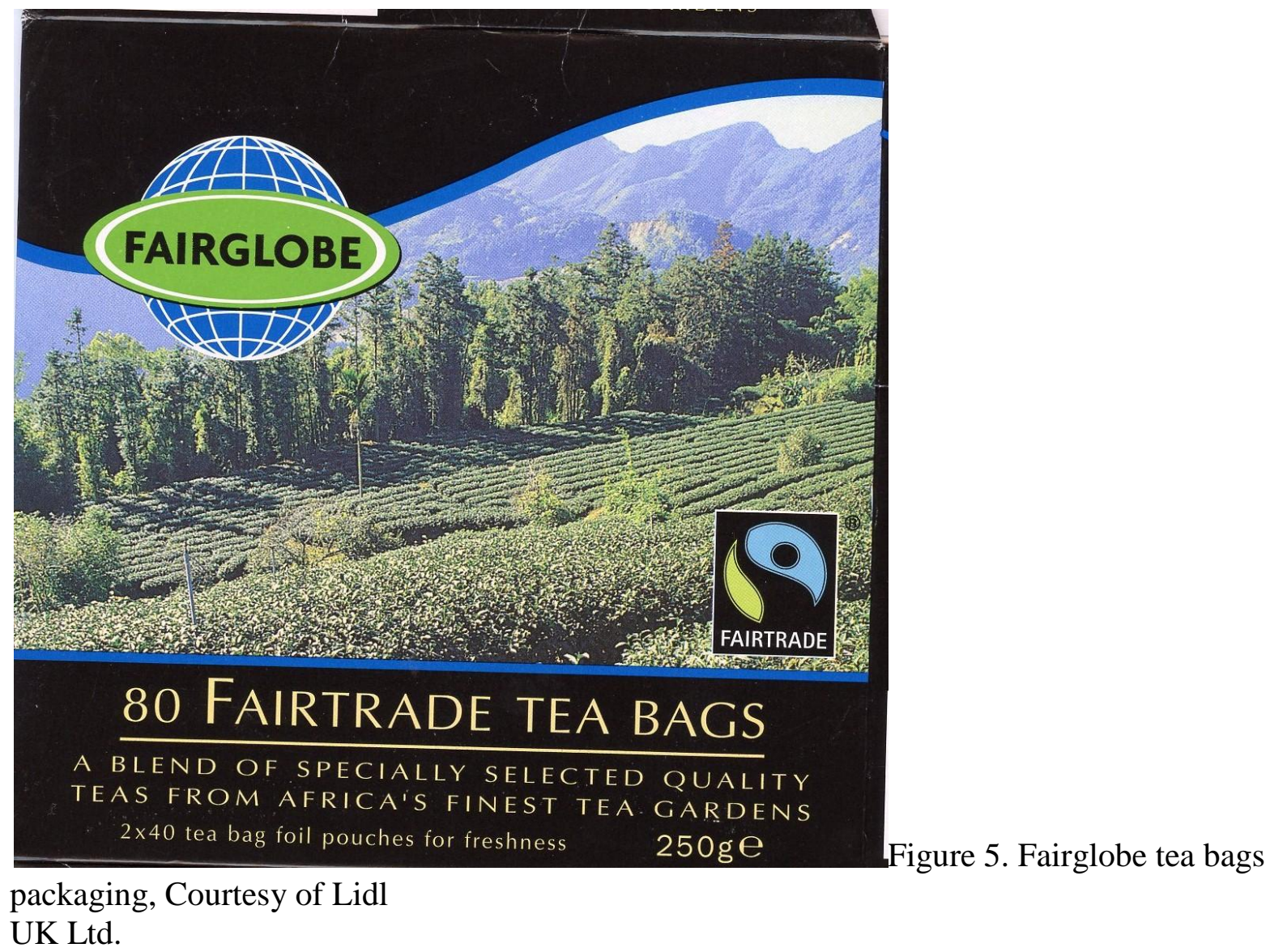

Finally, I return from smile to location. The visualizations of both space and subject work together to create meaning. The spaces depicted in fair trade advertising, the plantations and visions of exotic and idyllic rural beauty evoke a romanticism which allows the smile, when present, to work with greater affect. The fair trade imagination, as Varul highlights, is 'dominated by agricultural and artisanal producers in Latin America, Sub-Saharan Africa and South Asia', which provide 'traditional settings for all sorts of daydreaming activities of white Europeans and North Americans, Joseph-Conrad-Land' .48 The symbolic romanticism of such images has even enabled such spaces of hard labour to become tourist destinations.49 The exoticized space of labour, photographed as picturesque, evokes feelings of environmental responsibility, romantic rural idylls, stasis and tranquillity (Figure 5) - the opposite of the experience 
of industrial labour. It is almost impossible therefore to consider the workers visualized in such spaces as carrying out tasks that involve sweat and

hard labour.

Notes

1 'Fair TradeGrowing Fastest in Mainstream Supermarkets', Environmental Leader,March 8, 2011, http://

www.environmentalleader.com/2011/03/08/fair trade-growing-fastest-inmainstreamsupermarkets/

2 Barnet, C., Clarke, N., Cloke, P. and Malpass, A., 'Articulating Ethics and Consumption', Working Paper

No. 17, ESRC/AHRB Cultures of Consumption Programme, 2004, 10.

3 Jo Littler, Radical Consumption: Shopping for Change in Contemporary Culture

(Maidenhead: Open

University Press, 2009), 6-9.

4 A. Ramamurthy, Imperial Persuaders: Images of Africa and Asia in British

Advertising (Manchester:

Manchester University Press, 2003).

5 W. Leiss, S. Kline, S. Jhally and J. Botterill, Social Communication in Advertising:

Consumption in the

Mediated Marketplace, (London: Routledge, 2006).

6 A. Ramamurthy, 'Constructions of Illusion: Photography and Commodity Culture', in

Photography: A

Critical Introduction, 2nd edn, ed. Liz Wells (London: Routledge, 2000), 183.

7 Kathi Weeks, 'Life Within and Against Work: Affective Labor, Feminist Critique, and

Post-Fordist

Politics', Ephemera, 7, no. 1 (2007): 233-249, http://www.ephemeraweb.org

8 M. Hardt and A. Negri, Empire (Cambridge, MA: Harvard University Press, 2000), 290.

9 Maurizio Lazzarato, 'Immaterial Labour', http://www.generation-online.org/c/

fcimmateriallabour3.htm

10 Ramamurthy, Imperial Persuaders, chs 3 and 4.

11 Ibid., 106-117.

12 Brian Massumi, 'Notes on the Translation and Acknowledgements', in A Thousand

Plateaus, by Gilles

Deleuze and Felix Guattari, trans. Brian Massumi (Minneapolis, MN: University of

Minnesota Press,

1987).

13 Eric Shouse, 'Feeling, Emotion, Affect', M/C Journal: A Journal of Media and

Communication 8, no. 6 (2005),

http://journal.media-culture.org.au/0512/03-shouse.php

14 Encarnaci'on Guti'errez-Rodr'1guez, Migration, Domestic Work and Affect: A

Decolonial Approach on Value

and the Feminization of Labor (London: Routledge, 2010), 5.

15 Gilles Deleuze, 'Lecture Transcripts on Spinoza's Concept of Affect', 1978, http://www.

webdeleuze.com/php/texte.php?cle $=14 \&$ groupe $=$ spinoza\&langue $=2$

16 See Heath Schenker, 'Women, Gardens, and the English Middle Class in the Early.

Nineteenth

Century', in Bourgeois and Aristocratic Cultural Encounters in Garden Art, 1550-

1850, by Michel Conan 
(Cambridge, MA: Harvard University Press, 2002); Letty M. Russell, Kwok Pui-lan, Ada Maria Isasi-

Diaz and Katie Geneva Cannon, eds, Inheriting Our Mothers' Gardens: Feminist

Theology in Third World

Perspective (Louisville, KY: Westminster John Knox Press, 1988); 'Cultivating Guilty

Little Pleasures',

http://womensgarden.com/

17 Michel Foucault, 'Of Other Spaces', aka 'Heterotopias', 1967,

http://foucault.info/documents/

heteroTopia/foucault.heteroTopia.en.html

18 Encarnaci'on Guti'errez-Rodr'1guez, 'Reading Affect: On the Heterotopian Spaces of

Care and Domestic

Work in Private Households', Forum: Qualitative Social Research 8, no. 2 (2007).

19 Ann L. Stoler, 'Making Empire Respectable: The Politics of Race and Sexual Morality in 20th-Century

Colonial Cultures', American Ethnologist 16, no. 4 (1989): 634-660.

20 Stephen Constantine, "'Bringing the Empire Alive": The Empire Marketing Board and Imperial

Propaganda, 1926-33', in Imperialism and Popular Culture, ed. John M. MacKenzie

(Manchester:

Manchester University Press, 1986); Stephen Constantine, Buy and Build: The Advertising

Posters of the

Empire Marketing Board (London: Her Majesty's Stationery Office, 1986).

21 Guti'errez-Rodr'1guez, Migration, 1.

22 M. Foucault with G. Raulet 'Structuralism and Post Structuralism: An Interview with

Michel Foucault',

Telos 55 (Spring 1983): 195-211.

380 absences and silences

Downloaded by [Anandi Ramamurthy] at 10:09 17 November 2012

23 Guy Debord, 'Society of the Spectacle', 1967,

http://www.marxists.org/reference/archive/debord/

society.htm; Douglas Kellner, Media Spectacles (London: Routledge, 2003); Stuart Ewen, Advertising and

the Social Roots of the Consumer Culture (New York: McGraw Hill, 1976).

$24 \mathrm{http}: / /$ crystal-cure.com/orange.html

25 Ren'ee Chappelle, 'The Resurgence of Orange', Gourmet Retailer 26, no., (2005): 170171 ,

26 Max Havelaar, Fair trade website,

http://www.maxhavelaar.ch/en/maxhavelaar/foundation/

27 Sarah Kember, 'The Shadow of the Object : Photography and Realism', Textual Practice 10, no. (1996).

28 The insertion of the monkey into the plantation in replacement of the non-white worker also draws us

back to the racist association of black people to monkeys - 'themissing link' - legitimating exploitation. It

is an image that was cleverly adopted by PG Tips in their television advertising from the 1950s onwards

where the white consumer watched the attempts of the chimpanzees to act 'civilized',

drinking tea and 
speaking in the Queen's English. In advertisements such as this race and class hierarchies work together

for effect. See, e.g., PG Tips time line at http://www.pgtips.co.uk/timeline/

29 I. Hudson and M. Hudson, 'Removing the Veil? Commodity Fetishism, Fair Trade, and the

Environment', Organization \& Environment 16, no. 4 (2003): 413, 430.

30 Ibid., 419.

31 L.T. Raynolds, 'Re-embedding Global Agriculture: The International Organic and Fair Trade

Movements', Agriculture and Human Values 17, no. 3, (2000): 298.

32 Matthias Zick Varul, 'Consuming the Campesino: Fair Trade Marketing between

Recognition and

Romantic Commodification', Cultural Studies 22, no. 5 (2008): 654.

33 Littler, Radical Consumption, 30.

$34 \mathrm{http}: / / \mathrm{www}$. fairtrade.org.uk/resources/photo_library/images.aspx.

35 Kalpana Wilson, “'Race”, Gender and Neoliberalism: Changing Visual Representations in

Development', Third World Quarterly 32, no. 2 315-331; Kalpana Wilson, ‘Agency', in The Impact of

Feminism on Political Concepts and Debates, ed.G. Blakeley andV. Bryson

(Manchester: Manchester

University Press, 2007), 126-145.

36 Wilson, "“Race', Gender and Neoliberalism', 324.

37 Marilyn Frye, 'Oppression and the Use of Definition'. in The Politics of Reality:

Essays in Feminist Theory

(Trumansburg, NY: The Crossing Press, 1983).

38 Arlie Russell Hochschild, The Managed Heart: Commercialization of Human

Feeling (Berkeley, CA, and

London: University of California Press, 1983), quoted in Patricia Chong, 'Servitude with a Smile: An

Anti Oppression Analysis of Emotional Labour', Global Labour University Working

Papers, No 7 (Berlin,

2009).

39 Foucault and Raulet, 'Structuralism and Post Structuralism', 195-211.

40 Annette Beasley and LisaH. Amir) 'Infant feeding, poverty and human development', International

Breastfeeding Journal 2, no. 14 (2007): 4,

http://www.internationalbreastfeedingjournal.com/content/

$2 / 1 / 14$.

41 http://www.cafedirect.co.uk/meet-the-growers/uganda/mpanga

$42 \mathrm{http} / / / \mathrm{www}$. cafedirect.co.uk/meet-the-growers/kenya/kiegoi

43 Varul, 'Consuming the Campesino', 658.

44 From Fairglobe Tea Bags, Lidl, 2012.

45 The Bitter Taste of Tea: A Journey into the World of Fair Trade, dir. Tom

Heinemann (2007).

46 http://www.fairtrade.net/what_is_fairtrade.html, website of Fairtrade International, emphasis

added.

47 Simon Rawles, http://simonrawles.photoshelter.com/gallery/Uganda-fairtrade-tea/ G0000D4C.B5bOAuQ/; http://simonrawles.photoshelter.com/gallery/Uganda-fairtrade-tea/ 
G0000D4C.B5bOAuQ/

48 Varul, 'Consuming the Campesino', 661.

49 See Ceylon Tea Trails, http://www.teatrails.com

Anandi Ramamurthy 381

Downloaded by [Anandi Ramamurthy] at 10:09 17 November 2012 